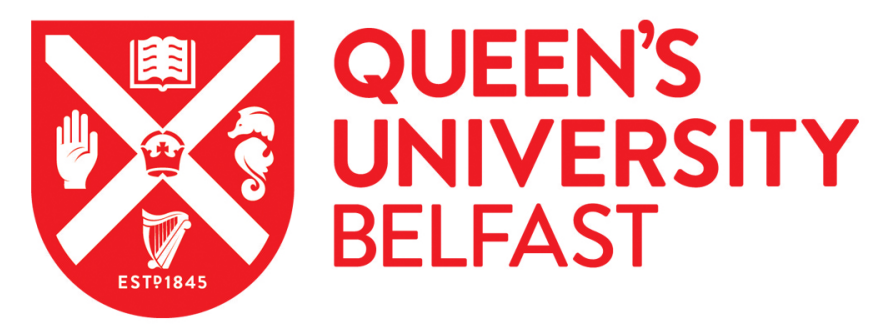

\title{
Calling it Quits: Legislative Retirements in Comparative Perspective
}

Raymond, C. D., \& Overby, L. M. (2019). Calling it Quits: Legislative Retirements in Comparative Perspective. Political Studies. https://doi.org/10.1177/0032321719865111

\section{Published in:}

Political Studies

\section{Document Version:}

Peer reviewed version

Queen's University Belfast - Research Portal:

Link to publication record in Queen's University Belfast Research Portal

Publisher rights

(C) 2019 The Authors.

This work is made available online in accordance with the publisher's policies. Please refer to any applicable terms of use of the publisher.

\section{General rights}

Copyright for the publications made accessible via the Queen's University Belfast Research Portal is retained by the author(s) and / or other copyright owners and it is a condition of accessing these publications that users recognise and abide by the legal requirements associated with these rights.

Take down policy

The Research Portal is Queen's institutional repository that provides access to Queen's research output. Every effort has been made to ensure that content in the Research Portal does not infringe any person's rights, or applicable UK laws. If you discover content in the Research Portal that you believe breaches copyright or violates any law, please contact openaccess@qub.ac.uk. 


\title{
Calling it Quits: Legislative Retirements in Comparative Perspective
}

\author{
Christopher D. Raymond \\ Queen's University Belfast \\ and \\ L. Marvin Overby \\ University of Missouri
}

\section{Key Words}

Legislatures; parliaments; parliamentary careers; retirement; ideology

\begin{abstract}
Although retirements are a major source of legislative turnover, research on the topic has been limited, especially outside of the US House of Representatives. In this paper, we address this shortcoming by examining retirements in two countries with similar electoral systems yet different legislative environments and party systems: Canada and the United Kingdom. In particular, we extend analysis on the Congress that has consistently shown Republican members retire at higher rates than their Democratic counterparts to examine whether this finding is generalizable to legislators from other parties of the right and/or favouring devolution in other parliamentary settings. In presenting data that support many of these hypotheses, we explore an important normative implication: because their partisan predispositions make them less willing to serve, politicians from parties favouring limited government and/or devolution may be less able to translate their vision of politics into policy because they face systemic problems maintaining legislative seats.
\end{abstract}

\section{Biographies}

Christopher Raymond is Lecturer in Politics in the School of History, Anthropology, Philosophy, and Politics at Queen's University Belfast. His published research has appeared in Political Studies, Parliamentary Affairs, Party Politics, and Journal of Legislative Studies, among others.

L. Marvin Overby is a Professor in the Department of Political Science at the University of Missouri. His published research has appeared in such journals as the American Political Science Review, the American Journal of Political Science, the Journal of Politics, Legislative Studies Quarterly, Political Research Quarterly, Journal of Legislative Studies, and Party Politics. 
${ }^{1}$ Analyses of legislators' career decisions in the United States Congress have yielded two consistent results: voluntary departures (i.e., retirements) exceed non-voluntary ones (i.e., electoral defeat) and Republicans retire at higher rates than Democrats. To date, however, the generalizability of these findings has not been tested, since most of the research on this topic has been limited to the US House of Representatives. Is the US House an outlier in terms of legislative turnover? Are House Republicans typical of other conservative legislators in their willingness to walk away from legislative careers? In the US, even the Senate (but see Bernstein and Wolak, 2002; Masthay and Overby, 2017) and state legislatures have received scant analytical attention when it comes to career decisions. While the literature examining the determinants of voluntary and involuntary legislative turnover in legislatures outside the US has expanded in recent years, the research on partisan differences in legislative retirements has not.

The lack of attention to this issue belies its importance. Though the comparative literature has yet to examine partisan differences in the rates of retirement, the impact such retirement rates have on parties' fortunes has received attention, particularly among party activists (e.g., Wallace, 2017). The fact that previous research finds evidence of personal incumbency advantages benefitting incumbents' parties (Cain et al., 1987; Norris and Lovenduski, 1995; Kendall and Rekkas, 2012; Hallam Smith, 2013; Redmond and Regan, 2015), and given that across a variety of systems roughly two thirds of incumbent legislators are routinely re-elected (Matland and Studlar, 2004; Gouglas et al., 2018), the career decisions of sitting members have significant partisan implications for turnover in and composition of legislative chambers outside the US. ${ }^{2}$ If

\footnotetext{
${ }^{1}$ The authors would like to thank Pippa Norris, who generously shared the British Representation Study data with us, and the anonymous reviewers for several helpful suggestions that have strengthened our manuscript. All responsibility for any errors belongs with us.

${ }^{2}$ Given that the principal role of parliamentary backbenchers is to support their party's leadership through their party loyalty on most votes, experience in office may not be as
} 
retirement decisions disproportionately and consistently affect some parties more than others, this could have significant consequences for which parties are able to control chambers, form governments, and create policy.

In this paper, we begin to address this lacuna. Guided by work on the US House of Representatives, we analyse career decisions in the lower chambers of two parliaments with similar electoral systems but different party systems: the Houses of Commons in Canada (19932015) and the United Kingdom (1979-2017). The findings provide insights into whether the patterns observed in the US House of Representatives might be generalizable across countries, institutions, and political systems. Similar to Republicans in the US, we find that right-of-centre MPs are more likely to retire in a given term than those on the left, that MPs belonging to parties viewed as being 'the natural party of government' are less likely to retire than MPs from other parties, and that MPs from parties favouring devolution are more likely to leave for other offices than MPs from other parties. These results have an important normative implication: because their MPs' personal preferences make them less willing to stay in office, parties favouring limited government and/or devolution may face greater difficulty holding onto the seats necessary to form governments and enact their preferred policies.

\section{Legislative Retirements: The View from the US House of Representatives}

In his classic study of political careers, Schlesinger (1966) developed a threefold categorization for political ambition: 'static' ambition where politicians seek to make a long

important for parliamentary backbenchers as it is for members of Congress, who become more engaged, specialised, and efficient with seniority (see Hibbing, 1991). However, it seems reasonable to expect that even in parliamentary settings retirements come with internal costs (in terms of expertise, familiarity with policies and personnel, and administrative efficiency) as well as electoral costs resulting from the loss of incumbency advantage. 
political career in a particular office; 'discrete' ambition wherein politicians desire office for a specified time only to then withdraw from public life; and 'progressive' ambition where politicians aspire to other offices they hold in higher regard. After accounting for legislative turnover due to involuntary departures (e.g., electoral defeat, though also including the relatively rare cases of expulsion and death in office), the differences between those with static ambition and those with either discrete or progressive ambition relate to differences in voluntary departures. Accordingly, a large body of research on the US House of Representatives has sought to understand and explain members' voluntary departures from office.

In the US, where incumbent re-election rates often exceed 90 percent, voluntary retirements have become the principal source of turnover in Congress. Voluntary retirements were a common feature of nineteenth century congresses, with biennial turnover rates frequently surpassing 40 percent. This was unsurprising given that service in a 'pre-institutionalised' Congress offered little political reward to ambitious politicians. By the late 1800 s, however, the federal government had assumed greater duties and Congress had developed into an institutionally more mature body. This dramatically increased the value of House seats and incumbency, resulting in a marked reduction in turnover, especially voluntary retirements. By the mid-1950s, the House had become the abode of long-serving career politicians (Bullock, 1972), and scholars began to assume that incumbents' political ambitions were driven principally if not solely by the desire for re-election (Mayhew, 1974).

Even as this new perspective was coalescing into conventional wisdom, the reality on the ground was shifting, with the 1970s experiencing an unanticipated surge in voluntary departures from the House, even as re-election rates for incumbents remained high. Cooper and West (1981) pointed to increasingly lengthy sessions, increasingly complex policy issues, increasingly diverse 
constituency demands, and increasingly wearisome fund-raising requirements, concluding 'the job is not fun anymore'. Hibbing (1982) indicted institutional and partisan changes in the House, particularly the move away from seniority norms, which had increased the value of tenure by guaranteeing committee leadership roles to long-serving members of the majority party. Other scholars concentrated on the calculations of individual members of Congress (MCs). Jacobson and Kernell (1983) argued that retirement decisions resulted from personal assessments of the estimated costs and benefits of seeking re-election, especially when weighted by the national political forces at play in particular election cycles. Kiewiet and Zeng's (1993) expected utility model, derived from labour economics, found that - unexpectedly - age was not a significant predictor of congressional retirements, but found support for Hibbing's institutional reform theory. Similarly, Hall and van Houweling (1995) found that members' individual fiscal circumstances and their prospects for further advancement in the chamber were the principal influences on retirement decisions. Switching attention back to political factors, Moore and Hibbing (1998) found older members, those who were electorally vulnerable, those less senior (in comparison to their age), and members at ideological odds with their parties more likely to retire over the 1960-1996 period.

Shifting from causes to their consequences, Gilmour and Rothstein $(1993,1996)$ showed that retirement decisions have important implications for partisan control of the House of Representatives. Focusing on the unattractiveness of long-term minority status and analysing the period from 1954 to $1990,{ }^{3}$ they found that voluntary departures 'cost the Republicans anywhere from 5 to 15 seats in the House', fully 20 percent of their deficit relative to the Democrats (1993,

\footnotetext{
${ }^{3}$ For an overview of the psychology literature on this point, see Humphrey et al. (2007) whose meta-analysis confirms that such features as autonomy, authority, and significance - all of which are enhanced in a cabinet position - are associated with overall job satisfaction.
} 
p. 358). Ang and Overby (2008) extended the time series forward and capitalised on the natural experiment offered by Republican control of the House between 1994 and 2006. Their finding that, even when in the majority, House Republicans retired at higher rates than Democrats led them to reject Gilmour and Rothstein's minority party hypothesis.

Instead of members' dissatisfaction with minority-party status, differences in retirement rates between parties may reflect underlying differences in politicians' orientations toward government. Three factors - ideology, political opportunities, and private sector opportunities have been examined as possible explanations of the partisan differences in retirement rates. Using data on House career decisions between the $97^{\text {th }}$ and $108^{\text {th }}$ Congresses, (1997-2004), Murakami (2009) found that conservatism was the primary motivator among House members leaving public office, while both ideology and political opportunities (specifically plausible paths to Senate and gubernatorial seats) motivated those leaving the House for other offices; private sector opportunities (as measured by previous career experiences) had no significant effect on retirements. In addition to providing a lucid argument for why conservatively inclined politicians, who are generally disinclined to hold government office, might prefer governorships or Senate seats to secure spots in the House (e.g., the veto pen held by governors and the filibuster threat wielded by senators are more useful for shortening than expanding government's reach), Murakami also shows that ideology matters within parties as well as between parties, with relatively conservative members on both sides of the aisle more likely to leave the House voluntarily.

\section{Retirement in Comparative Perspective}

As noted above, outside of the US House of Representatives few studies have examined 
legislative retirements to determine whether there is a partisan dimension to such career decisions. In a study of retirements from the contemporary Senate (1974-2014), Masthay and Overby (2017) find that - as in the House - retirements have far outstripped electoral defeats as a source of legislative turnover, with more than 1.75 retirements for each electoral defeat in the period. However, as Murakami (2009) speculated, unlike in the House there is no partisan differential in retirement rates between Democrats and Republicans. Though less attention has been given to the study of retirements in legislatures outside the US Congress, a growing body of research has emerged in recent years, finding patterns in legislative turnover that are similar to those observed in the US: for instance, as in the US, electoral defeats in other legislatures are far less common than other forms of turnover (Gouglas and Maddens, 2019).

While these works have not explicitly examined partisan differences in retirements, the findings in much of this research suggest partisan differences in retirements similar to those seen in the US are likely to be found. For one, some research has found that Members of Parliament (MPs) belonging to opposition parties (particularly MPs from the smallest parties) are more likely to retire than governing-party MPs (e.g., Kerby and Blidook, 2011). Because the government/opposition dynamic is more important in many legislatures outside the US, this suggests the possibility of partisan differences in retirement rates due to differences between government and opposition MPs.

Other research has examined differences in retirement due to ambitions for holding other offices (Stolz, 2003; Borchert, 2011; Borchert and Stolz, 2011). While 'progressive ambition' in the US context has usually implied running for national-level offices (except in the cases where MCs run for a state governorship), the devolution of authority to lower levels of government in other countries has opened opportunities for legislators preferring local to national policymaking 
to retire from national parliaments in pursuit of electoral ambitions in these 'lower-level' legislatures (Stolz, 2011; Vanlangenakker, Maddens, and Put, 2013; Dodeigne, 2014, 2018), with particular turnover in countries where legislative authority in devolved governments is greatest (Gouglas et al., 2018). Similar to Republican MCs preferring that decisions be made by state governments retiring from federal office more often than federally-oriented MCs, this suggests that MPs from parties preferring the devolution of powers to lower levels of government may retire in pursuit of these offices at higher rates than MPs from other parties. While we certainly do not mean to exaggerate the similarities between American Republicans and regional parties in the UK and Canada - indeed, the regional parties we consider here, the Bloc Québécois and SNP, are both in the progressive, social democratic tradition - it seems intuitive that representatives who prefer that power be exercised somewhere other than Washington, London, or Ottawa should, ceteris paribus, be less interested in long-term careers in those cities. This may be particularly the case for SNP MPs in the wake of devolution, which created a new venue at their preferred level of government in which they could participate, leading many to leave Westminster (Borchert, 2011; Vanlangenakker, Maddens, and Put, 2013).

While Murakami (2009) did not find evidence of employment prospects influencing retirement from Congress, we might expect partisan differences in retirement rates in other countries due to differences in terms of MPs' employment prospects after leaving office. In the UK, previous research shows that Conservative MPs realised significant financial advantages after leaving office, being significantly more likely to work as directors of publicly traded firms and other high-paying positions, and accruing significantly more wealth, than Labour MPs (Eggers and Hainmueller, 2009). Moreover, because MPs from right-of-centre parties have until recently (e.g., Evans and Tilley, 2017) - been more likely than left-of-centre MPs enter 
Parliament from middle-class occupations (business, law, etc.) that set up lucrative employment prospects following their retirement from office and/or lure right-of-centre MPs to return to the private sector, we might expect significant partisan differences in discrete career ambitions, with MPs from rightist parties more likely to retire to return to their former careers than leftist MPs.

Finally, we might also expect partisan differences in retirement due to ideological differences among the parties' MPs. Like their Republican counterparts, MPs from right-ofcentre parties may be significantly more likely to hold discrete career ambitions, and thus to retire from politics altogether at each election, than other parties' MPs due to their ideological dispositions. We do not want to overdraw the similarities between the Republicans in the US and right-of-centre parties elsewhere. Clearly, there are differences, with British and Canadian Conservatives being less far to the right than Republicans on a host of issues from morality matters to environmentalism (see Volkens et al., 2016). But there are some notable similarities, especially regarding the proper role of government (smaller) and its place in society (more limited): a look at the British Conservative Party's recent manifestos demonstrates their longstanding commitments to capitalism and free markets, reduced regulation, low taxes and free trade, reforming welfare to move more people into work, and a strong national defence. Similarly, the Conservative Party of Canada's May 2016 'Policy Declaration' endorses such priorities as a simplified tax code, balanced budgets, and reduced taxes on businesses and capital gains. Its 'belief that a responsible government must be fiscally prudent and should be limited to those responsibilities which cannot be discharged reasonably by the individual or others' would certainly be embraced by most Republicans (Conservative Party of Canada, 2016).

While the rightist ideological orientations of conservative parties' MPs might make many of these parties' MPs more likely to retire than others, a partisan disposition particular to the UK 
Conservatives might make these MPs less likely - net of other factors - to retire from office than conservative politicians in the US and Canada. For one, British Conservatives have long styled themselves as 'the natural party of government' - in ways akin to the parties of government in the US (the Democrats) and Canada (the Liberals). ${ }^{4}$ Perhaps more important is the fact that while the largest left-of-centre parties in the US and Canada have been ideologically left-liberal, the British Conservatives' main opponent is the social-democratic Labour Party. While the right in the US and Canada de-emphasises central authority, Conservatives in Britain have combined 'a traditional liberal defence of the free economy with a traditional conservative defence of state authority' (Gamble, 1994, pp.35-36), willing to use the state to undo what they perceive as the damage wrought by social democracy and to restore the British values that supported a free market in earlier days (p.43). As a result, British Conservatives may be more willing to sit in government to preserve state authority against the left (Gamble, 1994, pp.65-68). The tension between their ideological orientations and partisan desire to remain in office may well muddle any effect of party on British Conservative MPs' career choices.

\section{Examining Retirement in Canada and the United Kingdom}

To explore whether there may be partisan differences in the retirement rates of legislators in other countries, we examine individual decisions to retire in Canada (between the years 1993 and 2015) and the UK (between the years 1979 and 2017). Except for data taken from Norton (1999) for the period from 1979-1997 in the UK, data were collected by the authors. Studying these two countries allows us to examine legislatures with similar electoral systems (Canada and the UK use single-member plurality to elect MPs) but with different party systems. Because we

\footnotetext{
${ }^{4}$ For the US, see Ehrenhalt (1992). For Canada, see Carty (2015).
} 
have variation in the number and types of parties elected to the parliaments of each country, we can explore what sorts of factors might explain any partisan differences in retirement rates across these countries by exploiting the variation in the parties. Thus, we have control over the general contexts in which elections are conducted, which permits comparison with the US.

The dependent variable measures two types of voluntary departure. After examining all retiring MPs, we coded those MPs who voluntarily stood down during or at the end of a parliamentary term and did not seek other office as one, while those who stood down to pursue careers in other offices were coded as two. MPs running (successfully or not ${ }^{5}$ ) for re-election are coded zero. ${ }^{6}$

While most retirements are likely to be retirements from politics reflecting discrete ambitions, other MPs in these two countries may choose to move from national-level politics to the office at other levels of government. For a variety of reasons, however, such moves are rare. Docherty (2011) argues that the contemporary Canadian political career structure is characterised by 'free agency' and the corresponding lack of a single political career pattern. Canada historically had low levels of permeability between the different levels of government (Barrie and Gibbins, 1989). The national and regional parties are and have been distinct political entities, with different parties operating at the national and provincial levels, resulting in the development of alternative career patterns with politicians focused on one level of government or the other, with little movement between the two (Barrie and Gibbins, 1989; Detterbeck, 2011; Docherty, 2011; Pow, 2018). The UK has also developed distinct career paths for regional and national

\footnotetext{
${ }^{5}$ To determine whether the results are affected by including defeated MPs alongside those MPs successfully winning re-election in the baseline, we also estimated models excluding defeated MPs (see the supplementary file).

${ }^{6}$ We exclude those who died in office during the parliamentary term in which they passed away.
} 
politicians following devolution. While there was considerable movement of MPs from Westminster to the inaugural Scottish Parliament in 1999, the lower levels of office switching in subsequent elections indicate that a pattern of alternative career paths has emerged (Stolz, 2011). At least prior to the UK's stated intention to leave the European Union, progressive ambition may also take the form of MPs seeking election to the supranational European Parliament though there is little evidence to suggest that many MPs used their national legislatures as a springboard for a European political career (Stolz, 2003). ${ }^{7}$

Additionally, some MPs leave the lower house for careers in the upper chamber. The upper chambers of both countries are constitutionally subordinate to the lower chamber, with members of the upper chamber appointed (bar 92 hereditary peers in the UK since the House of Lords Act 1999) rather than elected. While some MPs do actively seek appointment to these upper chambers, the fact the House of Lords and the Canadian Senate cannot compare with the US Senate in terms of resources, power, or prestige means this number is low. While the numbers leaving the House of Commons for all other political offices are lower than those leaving politics altogether, ${ }^{8}$ separating the two types of retirement decisions ensures that we do not ignore differences in the effects of different variables on MPs' decisions.

Our primary variables of interest are variables measuring the party affiliation of members. Prior to 2003, the right in Canada was divided between the Progressive Conservatives and the Reform Party (going by the name of the Canadian Alliance from 2000-2003) from 1987 until the merger that produced the present Conservative Party in 2003. To determine whether the

\footnotetext{
${ }^{7}$ In addition to the European Parliament, MPs may also have sought appointment to the even more important (yet unelected) role of Commissioner.

${ }^{8}$ Retiring MPs and MPs pursuing another office constitute 12.37 and 2.05 percent, respectively, in Canada and 10.05 and 3.89 percent of the sample, respectively, in the UK.
} 
less conservative Progressive Conservative MPs were less likely to retire than Reform MPs, we include separate variables for Progressive Conservative and Reform/Conservative MPs. We also include variables measuring those belonging to the anti-federalist/pro-sovereignty Bloc Québécois (who, by dint of these orientations, should be more likely to quit Parliament in favour of elected office in Québec than MPs belonging to other parties) and the left-of-centre New Democratic Party (NDP). After excluding the handful of MPs elected as independents, this leaves MPs from the Liberal Party (viewed by many as the party of government given their long stays in office during the twentieth century and the presence of many Liberal-sympathisers in the bureaucracy) as the baseline.

In the UK, we include a dummy variable measuring those belonging to the Conservative Party. We also include a variable measuring MPs belonging to the Liberal Democrats, ${ }^{9}$ as well as a variable for the Scottish National Party (SNP), as SNP MPs may - similar to Bloc Québécois' MPs - prefer to influence policy at Holyrood, and thus depart Westminster earlier than MPs belonging to other parties. We omit MPs representing from Northern Ireland, as well as MPs representing the Welsh nationalist Plaid Cymru, due to the small number of MPs for these parties. After the handful of MPs elected as independents are also excluded, this leaves the Labour Party (the major party of the centre-left, which favours greater government involvement in economic and other matters of daily life) as the baseline.

Several variables allow us to examine other factors that might produce partisan differences in retirement. We include two variables that might lead opposition parties' MPs to retire at higher rates than government MPs. One variable measures whether MPs were members

\footnotetext{
${ }^{9}$ The results of models treating Liberals as distinct from the Social Democrats (who cooperated in Parliament and elections from 1981 until 1988 when the two parties formally merged) produce similar results to those seen below.
} 
of the cabinet during the parliamentary term. Because being a member of the cabinet means real authority, MPs holding a cabinet post are less likely to retire than MPs not in government. Because being in government means better access to those in power and the spoils that come with holding office, a second variable tests whether MPs belonging to the governing party (coded one) may be more willing to stay in office than opposition-party MPs (coded zero).

We also test the possibility that future employment prospects influence retirement decisions. To account for such differences in MPs' post-parliamentary career prospects, we include three variables measuring MPs' employment backgrounds prior to entering Parliament: business, law, and journalism. Each variable is coded one if MP was employed in the listed occupation prior to entering Parliament (and zero otherwise) using information from MPs' websites, biographies in the press, and (where applicable) funeral notices. These variables allow us to test whether MPs employed in these fields prior to entering Parliament are more likely retire from politics to return to their (more lucrative and/or personally rewarding) former occupations than MPs from other backgrounds; because there may be partisan differences in the backgrounds of MPs formerly employed in these fields, controlling for these variables may help to account for any partisan differences in retirements.

We also examine the impact of several additional variables to control for the other prominent factors previous research has shown to influence MPs' retirement decisions. Because MPs are more likely to retire with age, we include MPs' (logged) age at the end of each term. Because MPs are more likely to retire the longer they sit in office, we also include a variable measuring the (logged) total number of years served at the start of each term.

We also include two variables to measure the political climate in which MPs find themselves - both personally and in terms of their parties. The first variable measures the size of 
MPs' mandates in the previous election: MPs with smaller vote percentages are less secure in their positions than MPs who won their seats with larger vote shares, and thus MPs with higher vote shares may be less likely to retire than MPs with lower vote shares. A second variable measures the political climate facing MPs' parties. When a party stands to win more seats in an election, the party's MPs will be less likely to retire, as it means they are more likely to be secure; when a party's fortunes are set to worsen, MPs may retire earlier than they otherwise would have. To capture this dynamic, we include a variable measuring the percentage change in seats for MPs' respective parties at each election. ${ }^{10}$

Additionally, because MPs may be more likely to retire once they have sat in office long enough to secure the potential retirement benefits offered to them (Kerby and Blidook, 2011), we also include variables designed to measure the effects of such benefits. In Canada, we include two dummy variables: one variable for when MPs first become eligible for retirement benefits and one for when they have maxed out their pensions. Because so many British MPs in our data set have sat in Parliament long enough to acquire the full benefits of office (which accrue after only five years of service), we include only a dummy variable measuring those who have not yet become eligible versus those who are eligible. Because the costs of office and contesting elections can be particularly demanding on female MPs (e.g., Lovenduski and Norris, 1996; Dolan, 2008; Thomas and Bittner, 2017), and because female MPs indicate they are more likely than male counterparts to be pushed out of office by party leaders (Vanlangenakker, Wauters,

\footnotetext{
${ }^{10}$ While the decision to retire occurs before the election is decided, MPs may be able to predict when their parties are likely to lose significant seat shares based on the feedback they receive from constituents (during constituency surgeries, in correspondences with constituents, etc.): consistently negative interactions in the run-up to elections would provide evidence that they and their party face difficult re-election prospects, which would lead some MPs to retire rather than face defeat. Additionally, there is some evidence they may be able to anticipate poor outcomes for their party based on pre-election opinion polling (see the supplementary file).
} 
and Madden, 2013), we include a variable coded one for female MPs and zero otherwise. To account for any period-specific effects that are not accounted for by variables above, we include parliamentary-term fixed effects.

\section{Results}

Table 1 presents the parameter estimates for the regression models estimating retirements in Canada, while Table 2 presents results from the UK. To estimate these models, we use multinomial logistic regression with standard errors clustered by MP. ${ }^{11}$ Several factors potentially affecting decisions to retire - e.g. age, tenure in office, political opportunities, political climate, and retirement benefits - reach statistical significance. However, the results also show that even after controlling for these factors, several partisan differences in retirement rates persist.

\section{Tables 1 and 2 about here}

Beginning with the case of Canada, the results show that after controlling for other factors, Reform (and later, Conservative) MPs were significantly more likely to retire than MPs from other parties. Holding all other variables at their median values, Reform/Conservative MPs are 5.78 percentage points more likely to retire from politics relative to the baseline. The same is not true of Reform/Conservative decisions to seek lower-level offices, as the coefficient is negative and statistically significant. These findings make sense given sceptical outlook on government involvement that has characterised the Reform and Conservative parties, which mirrors (even if it does not equal) the attitudes of many Republican MCs. Further evidence of this conclusion can be seen in the fact that MPs from the less conservative Progressive

\footnotetext{
${ }^{11}$ We use multinomial logistic regression (rather than survival models) because retirements, like in the US Congress, cluster at the end of each term after the general election has been called.
} 
Conservative Party are not significantly more likely to retire from politics than Liberal MPs.

The results from the Bloc Québécois variable suggest that MPs preferring government policy to be controlled by lower levels of government (or by a fully independent Québec) find the affairs of federal government less rewarding than others, and therefore retire from federal politics to run for lower-level offices at higher rates than Liberal MPs. ${ }^{12}$ Consistent with this explanation, the coefficients for Bloc Québécois MPs are positive and statistically significant predictors of running for lower-level office. Relative to the Liberal MPs and holding all other variables at their median values, Bloc Québécois MPs are 2.25 percentage points more likely to retire to run for lower-level office. Like Republican MCs who view federal government action as less legitimate than state government action, the fact that many Bloc Québécois MPs prefer government action to be taken at the provincial level (or, as the most ardent sovereigntists would prefer to say, the national level) would certainly explain this finding. While some Conservative MPs might share this preference for provincial powers as well, the fact that we observe such a finding among Bloc Québécois MPs provides the strongest evidence that such predispositions are at work leading MPs of this persuasion to retire earlier than MPs from other parties.

Turning to the results among British MPs, we note no significant association between Conservative MPs and retirement. This finding is interesting because, as noted above, many Conservative MPs are likely torn between their ideological predispositions and their partisan motivation to hold office to keep Labour out. Our data, indicating Conservatives are no more likely to retire than Labour MPs, suggest that these two sets of preferences largely cancel out.

While retirement rates do not differ between Conservative and Labour MPs, we observe that SNP MPs are particularly likely to retire to seek other political offices (though not to leave

\footnotetext{
${ }^{12}$ Of the 46 Bloc Québécois MPs who retired during this period, 15 (33 percent) left to
} participate in politics in Québec. 
politics altogether): SNP MPs are 24.24 percentage points more likely to retire from Westminster in favour of Holyrood than Labour MPs. While Labour MPs in England (outside London) have not had as many alternative career paths, ${ }^{13}$ the fact SNP MPs are more likely to leave Westminster in pursuit of other offices suggests that, similar to Bloc Québécois MPs, these MPs find politics in Westminster less rewarding due to their preference for devolved - or independent - government. These findings reinforce the conclusion drawn above with regard to the Bloc Québécois and suggest that MPs from parties favouring devolution are more likely to retire to lower levels of government than those favouring more unitary government action. This conclusion, in turn, suggests that at least part of the reason Republican MCs retire at higher rates than Democrats in the US is due to the preferences of the former for devolution of federal power to the states.

It is also worth noting that, despite their third-party status and lack of access to power throughout most of this period, the likelihood of retirement among NDP MPs is not significantly distinct from the baseline. The fact NDP MPs do not depart significantly earlier than Liberal MPs is in line with the NDP's even greater preference for government intervention in the economy and society. ${ }^{14}$ Liberal Democrat MPs are 5.61 percentage points less likely than Labour

\footnotetext{
${ }^{13}$ While other parties' MPs have sought several different offices (in Europe, at the local level, and in the House of Lords), analysis of the retirement decisions of SNP MPs shows that nearly everyone sought election to Holyrood. Although the bulk of these occurred before the first election to the Scottish Parliament, the fact remains that SNP MPs are significantly more likely to leave Westminster even after controlling for the fact that all MPs were significantly more likely to leave Westminster for other offices between 1997 and 2001 (i.e., with the fixed effect for this parliamentary term).

${ }^{14}$ The NDP's most recent policy book (https://xfer.ndp.ca/2018/Documents/2018-POLICY.pdf) includes a strong endorsement of the public sector, including 'protecting crown corporations against privatization .... Improving the public sector's role as a wealth creator and major provider of jobs .... Opposing all forms of privatization and in supporting the delivery of all public services by public sector workers'.
} 
MPs to retire from politics altogether, and instead are 10.11 percentage points more likely to seek other political offices. ${ }^{15}$ These findings - paired with the fact governing-party status has no significant effect in either country - support earlier research showing that minority-party status per se does not lead to higher retirement rates (Ang and Overby, 2008; Murakami, 2009).

Finally, it is interesting to note that MPs' career backgrounds have little effect on their probabilities of leaving office. In Britain, the lack of a significant positive relationship between Conservative MPs and retirement may be in keeping with recent research noting the rise in welleducated and career-orientated Labour MPs (e.g., Evans and Tilley, 2017), which may help to reduce partisan differences. The higher rates of retirement among Reform/Conservative MPs in Canada, however, are clearly not due to better career prospects outside of Parliament.

\section{Robustness Test: Examining the Impact of Ideology}

While the results showing partisan differences in the probabilities of retirement are in keeping with the expectations stated above, these models are unable to account for the impact of MPs' personal ideological dispositions (as opposed to the ideological profile of their parties) on their likelihood of retirement. To determine the impact of ideology on MPs' retirement decisions, we are able to reanalyse the British models including a survey measure of MP's ideology. ${ }^{16}$ Specifically, we use a measure of left-right ideology taken from three waves of the British Representation Study that allow us to examine retirements in advance of the 2001, 2005, and

\footnotetext{
${ }^{15}$ Liberal Democrat MPs sought a range of different offices, from local councils to Holyrood to the House of Lords.

${ }^{16}$ Unlike congressional studies, we are unable to control for MPs' left-right positions using measures like NOMINATE (see Poole and Rosenthall, 1997) due to the significantly higher levels of party discipline and cohesion, which render roll-call votes unrepresentative of MPs' ideological dispositions (e.g. Carrubba et al., 2006).
} 
2010 elections (Norris et al., 1997; Norris and Lovenduski, 2001; Lovenduski, Childs, and Campbell, 2005). ${ }^{17}$ In these surveys, MPs placed themselves along a left-right scale ranging from one (left) to ten (right). To account for the fact that most right-leaning MPs tend to belong to the Conservative Party, which leaves few right-leaning MPs in the baseline (and increasing the possibility of outlier effects among non-Conservative MPs), we use values of MPs' left-right self-placements. This allows us to test whether the experience of Republican MCs - where those placing themselves to the right are more likely to retire than MPs placing themselves to the left can be generalised.

Including the variable measuring MPs' left-right self-placements, we re-estimated the models of retirement from the British House of Commons, focusing on those who retired from politics altogether (and dropping the small number of MPs in the sample who retired to seek political office elsewhere). Due to the restriction of the time period, in which Labour is the governing party, we drop the variable measuring differences between government and opposition MPs, as well as the variable measuring changes in parties' seat shares. The results using logistic regression appear in Table 3.

\section{Table 3 about here}

\footnotetext{
${ }^{17}$ These surveys were collected from candidates in the run-up to the general elections of 1997 , 2001, and 2005. Though Conservative MPs were somewhat less likely to be included in the survey than Labour and Liberal Democrat MPs, the samples are quite representative of the parties' seat shares in Parliament. In 1997, Labour won 63 percent of the seats in the Commons (65 percent in the sample of MPs), the Conservatives won 25 percent (21 percent of the sample), the Liberal Democrats 7 percent (12 percent of the sample), and the SNP 1 percent (1 percent of the sample). In 2001: Labour 63 (70 percent of the sample), Conservatives 25 (23 percent of the sample), Liberal Democrats 8 (6 percent of the sample), SNP 1 (1 percent of the sample). In 2005: Labour 55 percent (53 percent of the sample), Conservatives 31 percent (29 percent of the sample), Liberal Democrats 10 percent (17 percent of the sample), SNP 1 (0 percent of the sample). The MPs included are representative of all other predictors used in Tables 1-3 except those with a background in law and with higher vote shares (both are less likely to be included in the sample).
} 
Table 3 suggests both ideology and career goals impact the likelihood of retirement. Leftright ideology is positively and significantly associated with retirement. This suggests, as with the case of Republican MCs in the US Congress, that right-of-centre politicians - who tend to prefer less government intervention in private economic and social affairs - are significantly more likely to retire than more leftist MPs. As seen in Figure 1, which plots the predicted probability of retirement across the range of left-right ideology (holding all other variables at their medians), MPs placing themselves farthest to the left have a 6.83 percent chance of retiring in any one term, while MPs placing themselves farthest to the right have a 32.0 percent chance of retiring. This 25 percentage-point difference means there is considerably more turnover among MPs on the right than on the left.

\section{Figure 1 about here}

Additionally, the results in Table 3 show that after controlling for MPs' left-right selfplacements, Conservative MPs become significantly less likely to retire than Labour MPs. In keeping with the notion that the party sees incumbency as important to keeping Labour out of office (Gamble, 1994, pp.65-68), Conservative MPs are 8.01 percentage points - holding all other variables at their median values - less likely to retire than Labour MPs. Similar to the Democrats in the US and the Liberals in Canada, the fact Conservative MPs are even less likely to retire than Labour MPs (the party in government at the time) is also in keeping with the Conservatives' notion as being the natural party of government (at least after accounting for leftright ideology).

\section{Discussion}

The results presented above provide several interesting insights regarding the decision to 
retire from legislatures. For one, the results confirm our initial intuition that partisan differences in retirement rates are not confined to the US. There, members of the Republican Party in the House of Representatives are more likely to retire from office than Democrats. In this analysis, in both Canada and the UK, we observe partisan differences in retirement rates that shed light on the findings seen in earlier research.

Our research design allows us to examine many of the arguments potentially explaining these partisan differences in retirement rates. The results presented above provide evidence that ideological dispositions are at work cross-nationally, leading members of certain parties to retire earlier than MPs from other parties. As with Republican MCs who are generally opposed on ideological grounds to government intervention in the economy, similarly predisposed Conservative MPs in Canada were significantly more likely to retire than MPs from other parties. Although we did not find evidence demonstrating a similar partisan difference between Conservative and other MPs in Britain, our results did show that right-of-centre MPs were significantly more likely to retire than left-of-centre MPs. Thus, in keeping with the findings from the study of American legislatures, right-of-centre legislators are more likely to retire early due to their ideological preferences.

A second explanation for partisan differences in retirement for which we find evidence is preference for independence/devolved government. Analogous to Republican preferences for government power to be vested in the states (as opposed to the federal government), MPs from parties devoted to such causes - the Bloc Québécois in Canada and the SNP in the UK - are significantly more likely to retire than MPs from other parties and seek other political offices in devolved governments. These results reflect in the other direction as well, suggesting that American Republicans, as a party preferring devolved government, are not unique in their 
aversion to national legislative service.

A third factor motivating retirements suggested by our analysis regards the impact of parties perceived as being 'the' party of government. Similar to the Republicans in the US, Conservatives in Canada are significantly more likely to retire than the Canadian party most clearly identified with government, the Liberals (akin to the Democrats in the US). Providing even clearer, more direct evidence in favour of such identities is the experience of the Conservatives in the UK: the fact Conservative MPs become less likely to retire than Labour MPs after accounting for left-right ideology provides at least moderately suggestive evidence that Conservative MPs are less likely to retire due to their perceived responsibility to govern (or at least to prevent Labour from governing: Gamble, 1994, pp.65-68). The absence of partisan differences in retirement between Conservative and Labour MPs before accounting for left-right ideological placements suggests many Conservative MPs are conflicted by their perceived duty to govern and their ideological predilection for less government.

These results carry important normative implications. Political decisions are made by those who participate (Dahl, 1961). If one party or another faces systemic difficulties in getting its supporters to stand for and hold elective office, that party surrenders a disproportionate share of the advantages of incumbency and seniority. Our research suggests that while the situation in individual cases varies, right-leaning, sub-nationalist, and other parties less fond of certain government activities (or government more generally) are structurally disadvantaged in the political realm; and, as Sprague noticed in 1981, even small differences in holding seats can be 'consequential'. Given that incumbents can use the resources of the office to improve their chances of re-election, lower levels of retention due to higher rates of retirement make the costs of holding onto power all the greater for these parties. Moreover, the increased costs of re- 
election for these parties mean it is harder for them to retain the seat shares in their respective legislatures needed to pass policies favourable to their voters. Though many right-of-centre parties possess structural advantages - like larger resource bases - over left-of-centre parties, the need to recruit candidates more frequently makes the cost of retirements more significant for parties on the right than parties on the left: while right-leaning parties - as well as nationalist parties of the right or left - sceptical of the work of national governments spend more time and resources recruiting candidates, left-leaning parties and politicians favourably disposed to the national government enjoy incumbency advantages that may give these parties an important electoral advantage.

While this paper has provided support for these arguments, the results presented here should not be considered conclusive. Admittedly, we have examined only two countries (and even then, only examined parliaments at the national level). More work testing this argument in other countries and at different levels of government - especially at lower levels of government that might give rise to progressive ambition, and perhaps even at the supra-national level (e.g., the European Parliament) - is needed to test the robustness of the tentative conclusions drawn here. Research examining the impact of institutional variation - differences in properties of the electoral system and differences in the institutional structure regarding backbench participation (such as committee structures, free votes, and the ability of backbench MPs to influence the agenda) - on partisan differences in retirement rates would be particularly welcome. That being said, the results are sufficient to compel us to treat the partisan differences in retirement rates seriously and to explore the empirical and normative consequences of these differences in future research. 


\section{References}

Ang AU-J and Overby LM (2008) Retirements, Retentions, and the Balance of Partisan Power in Contemporary Congressional Politics. Journal of Legislative Studies 14(3): 339-352.

Barrie D and Gibbins R (1989) Parliamentary Careers in the Canadian Federal State. Canadian Journal of Political Science 22(1): 137-145.

Bernstein JL and Wolak J (2002) A Bicameral Perspective on Legislative Retirement: The Case of the Senate. Political Research Quarterly 55(2): 375-390.

Borchert J (2011) Individual Ambition and Institutional Opportunity: A Conceptual Approach to Political Careers in Multi-level Systems. Regional and Federal Studies 21(2): 117-140.

Borchert J and Stolz K (2011) German political careers: the state level as an arena in its own right? Regional and Federal Studies 21(2): 205-222.

Cain B, Ferejohn J and Fiorina M (1987) The Personal Vote: Constituency Service and Electoral Independence. Cambridge: Harvard University Press.

Carey JM and Shugart MS (1995) Incentives to cultivate a personal vote: A rank ordering of electoral formulas. Electoral Studies 14(4): 417-439.

Carrubba CJ, Gabel M, Murrah L, Clough R, Montgomery E, and Schambach R (2006) Off the record: Unrecorded legislative votes, selection bias and roll-call vote analysis. British Journal of Political Science 36(4): 691-704.

Carty RK (2015) Big Tent Politics: The Liberal Party's Long Mastery of Canada's Public Life. Vancouver: University of British Columbia Press.

Conservative Party of Canada (2016) Policy Declaration. Accessed at: www.conservative.ca/media/documents/Policy\%20Declaration\%20\%20June\%2011\%202016.pdf). 
Cooper J and West W (1981) Voluntary Retirement, Incumbency, and the Modern House. Political Science Quarterly 96(2): 279-300.

Dahl RA (1961) Who Governs. New Haven, CT: Yale University Press.

Detterbeck K (2011) Party Careers in Federal Systems: Vertical Linkages within Austrian,

German, Canadian, and Australian Parties. Regional and Federal Studies 21(2): 245-270.

Docherty DC (1997) Mr. Smith Goes to Ottawa: Life in the House of Commons. Vancouver: University of British Columbia Press.

Docherty DC (2005) Legislatures. Vancouver: University of British Columbia Press.

Docherty DC (2011) The Canadian Political Career Structure: From Stability to Free Agency. Regional and Federal Studies 21(2): 185-203.

Dodeigne J (2014) (Re-) assessing career patterns in multi-level systems: Insights from Wallonia in Belgium. Regional \& Federal Studies 24(2): 151-171.

Dodeigne J (2018) Who governs? The disputed effects of regionalism on legislative career orientation in multilevel systems. West European Politics 41(3): 728-753.

Dolan K (2008) Women Candidates in American Politics: What We Know, What We Want to Know. In: Wolbrecht C, Beckwith K, and Baldez L (eds) Political women and American democracy. Cambridge: Cambridge University Press, pp.110-127.

Eggers AC and Hainmueller J (2009) MPs for Sale?: Returns to Office of Postwar British Politics. American Political Science Review 103(4): 513-533.

Ehrenhalt A (1992) The United States of Ambition: Politicians, Power, and Pursuit of Office. New York: Times Books.

Evans, G and Tilley J (2017) The New Politics of Class: The Political Exclusion of the British Working Class. Oxford: Oxford University Press. 
Gamble A (1994). The free economy and the strong state: The politics of Thatcherism. London: Macmillan.

Gilmour JB and Rothstein P (1993) Early Republican Retirement: A Cause of Democratic Dominance in the House of Representatives. Legislative Studies Quarterly 18(3): 345365.

Gilmour JB and Rothstein P (1996) A Dynamic Model of Loss, Retirement, and Tenure in the US House of Representatives. Journal of Politics 58(1): 54-68.

Gouglas A, Maddens B and Brans M (2018) Determinants of legislative turnover in Western Europe, 1945-2015. European Journal of Political Research 57(3): 637-661.

Gouglas A and Maddens B (2019) Legislative turnover and its sources: It's the selection. Politics 39(1): 101-112.

Hall RL and van Houweling RP (1995) Avarice and Ambition in Congress: Representatives' Decision to Run or Retire from the US House. American Political Science Review 89(1): $121-136$.

Hallam Smith T (2013) Are you sitting comfortably? Estimating incumbency advantage in the UK: 1983-2010 - A research note. Electoral Studies 32(1): 167-173.

Hibbing JR (1982) Voluntary Retirement from the US House of Representatives: Who Quits? American Journal of Political Science 26(3): 467-484.

Hibbing JR (1991) Congressional Careers: Contours of Life in the U.S. House of Representatives. Chapel Hill: University of North Carolina Press.

Humphrey SE, Nahrgang JD, and Morgeson FP (2007) Integrating Motivational, Social, and Contextual Work Design Features: A Meta-Analytic Summary and Theoretical Extension of the Work Design Literature. Journal of Applied Psychology 92(5): 1332-1356. 
Jacobson GC and Kernell S (1983) Strategy and Choice on Congressional Elections. New Haven: Yale University Press.

Kendall C and Rekkas M (2012) Incumbency Advantages in the Canadian Parliament. The Canadian Journal of Economics 45(4): 1560-1585.

Kerby M and Blidook K (2011) It's Not You, It's Me: Determinants of Voluntary Legislative Turnout in Canada. Legislative Studies Quarterly 36(4): 621-643.

Kiewiet R and Zeng L (1993) An Analysis of Congressional Career Decisions, 1947-1986. American Political Science Review 87(4): 928-941.

Lovenduski J and Norris P (eds) (1996). Women in Politics. Oxford: Oxford University Press. Lovenduski J, Childs S and Campbell R (2005) The British Representation Study 2005. London: Birkbeck College.

Masthay TJ and Overby LM (2017) Dynamics of Senate Retirements. Political Research Quarterly 70(1): 184-193.

Matland RE and Studlar DT (2004) Determinants of Legislative Turnover: A Cross-National Analysis. British Journal of Political Science 34(1): 87-108.

Mayhew DR (1974) Congress: The Electoral Connection. New Haven: Yale University Press. Moore MK and Hibbing JR (1992) Is Serving in Congress Fun Again? Voluntary Retirements from House Since the 1970s. American Journal of Political Science 36(3): 824-828.

Murakami MH (2009) Minority Status, Ideology, or Opportunity: Explaining the Greater Retirement of House Republicans. Legislative Studies Quarterly 34(2): 219-244.

Norris P, Lovenduski J, Heath A, Jowell R and Curtice J (1997) The British Representation Study 1997. London: Birkbeck College.

Norris P and Lovenduski J (1995) Political Recruitment: Gender, Race and Class in the British 
Parliament. Cambridge: Cambridge University Press.

Norris P and Lovenduski J (2001) The British Representation Study 2001. Norwich: University of East Anglia.

Norton P (1999) Free Votes in the House of Commons, 1979-1997 [computer file]. Colchester, Essex: UK Data Archive [distributor]. SN: 4056, http://dx.doi.org/10.5255/UKDA-SN4056-1.

Poole KT and Rosenthal H (1997) Congress: A Political-Economic History of Roll Call Voting. New York: Oxford University Press.

Pow JT (2018) Amateurs versus Professionals: Explaining the Political (in) Experience of Canadian Members of Parliament. Parliamentary Affairs 71(3): 633-655.

Redmond P and Regan J (2015) Incumbency advantage in a proportional electoral system: A regression discontinuity analysis of Irish elections. European Journal of Political Economy 38: 244-256.

Schlesinger JA (1966) Ambition and Politics: Political Careers in the United States. New York: Rand McNally.

Sprague J (1981) One-Party Dominance in Legislatures. Legislative Studies Quarterly 6(2): 259285.

Stolz K (2003) Moving Up, Moving Down: Political Careers Across Territorial Levels. European Journal of Political Research 42(2): 223-248.

Stolz K (2011) The Regionalization of Political Careers in Spain and the UK. Regional and Federal Studies 21(2): 223-243.

Thomas M and Bittner A (eds) (2017). Mothers and others: The role of parenthood in politics. Vancouver: University of British Columbia Press. 
Vanlangenakker I, Maddens B and Put GJ (2013) Career patterns in multilevel states: An analysis of the Belgian regions. Regional Studies 47(3), 356-367.

Vanlangenakker I, Wauters B and Maddens B (2013). Pushed toward the exit? How female MPs leave parliament. Politics \& Gender 9(1): 61-75.

Volkens A, Lehmann P, Matthiess T, Merz N, and Regel S (2016) The Manifesto Data Collection. Manifesto Project (MRG/CMP/MARPOR). Berlin: Wissenschaftszentrum Berlin für Sozialforschung (WZB). Version $2016 b$.

Wallace M (2017) Centralisation and chaos - inside the rush to select Conservative candidates in time for the election. Conservative Home. Available at: https://www.conservativehome.com/thetorydiary/2017/05/centralisation-and-chaosinside-the-rush-to-select-conservative-candidates-in-time-for-the-election.html. 
Table 1: Predicting Retirement from the Canadian House of Commons

\begin{tabular}{|c|c|c|}
\hline \multirow[b]{2}{*}{ Variables } & \multicolumn{2}{|c|}{ Outcome } \\
\hline & Left Politics & Other Office \\
\hline Reform/Conservative & $0.611(0.209)^{* * *}$ & $-0.526(0.593)$ \\
\hline Progressive Conservative & $0.283(0.557)$ & $1.200(0.952)$ \\
\hline Bloc Québécois & $0.342(0.298)$ & $1.144(0.549)^{* *}$ \\
\hline New Democratic Party & $0.049(0.311)$ & $-0.245(0.682)$ \\
\hline Cabinet Member & $-0.018(0.216)$ & $-1.349(0.671)^{* *}$ \\
\hline Governing Party & $-0.194(0.211)$ & $-0.691(0.681)$ \\
\hline Business Background & $-0.115(0.153)$ & $-0.007(0.364)$ \\
\hline Law Background & $-0.158(0.197)$ & $-0.263(0.465)$ \\
\hline Journalism Background & $0.268(0.278)$ & $0.338(0.602)$ \\
\hline Age & $3.962(0.565) * * *$ & $-0.998(0.796)$ \\
\hline Tenure & $0.892(0.251)^{* * *}$ & $1.333(0.584)^{* *}$ \\
\hline Vote Percentage & $-1.697(0.723) * *$ & $4.848(1.815) * * *$ \\
\hline Seat Change & $-1.249(0.820)$ & $-3.217(2.039)$ \\
\hline Pension Eligible & $0.389(0.286)$ & $1.435(0.864)^{*}$ \\
\hline Pension Maxed & $0.600(0.463)$ & $2.043(1.189)^{*}$ \\
\hline Female & $0.042(0.173)$ & $-0.063(0.446)$ \\
\hline Constant & $-17.031(2.259) * * *$ & $-3.922(3.126)$ \\
\hline Parliamentary Term Dummies & \multicolumn{2}{|c|}{ Yes } \\
\hline Likelihood Ratio $\chi^{2}$ & \multicolumn{2}{|c|}{$250.78 * * *$} \\
\hline McFadden's $\mathrm{R}^{2}$ & \multicolumn{2}{|c|}{0.18} \\
\hline MPs (Total n) & \multicolumn{2}{|c|}{840 (2177) } \\
\hline
\end{tabular}

$* \mathrm{p}<0.10,{ }^{*} \mathrm{p}<0.05, * * * \mathrm{p}<0.01$, two-tailed tests. Coefficients with standard errors clustered by MP in parentheses. 
Table 2: Predicting Retirement from the British House of Commons

\begin{tabular}{|c|c|c|}
\hline \multirow[b]{2}{*}{ Variables } & \multicolumn{2}{|c|}{$\begin{array}{l}\text { Outcome } \\
\end{array}$} \\
\hline & Left Politics & Other Office \\
\hline Conservative & $0.034(0.126)$ & $0.174(0.200)$ \\
\hline Liberal/Liberal Democrat & $-0.652(0.309)^{* *}$ & $1.745(0.296) * * *$ \\
\hline Scottish National Party & $0.191(0.622)$ & $3.150(0.481)^{* * *}$ \\
\hline Cabinet Member & $-0.542(0.252)^{* *}$ & $0.824(0.253) * * *$ \\
\hline Governing Party & $-0.008(0.137)$ & $0.233(0.223)$ \\
\hline Business Background & $-0.222(0.139)$ & $-0.486(0.209) * *$ \\
\hline Law Background & $-0.104(0.142)$ & $0.202(0.207)$ \\
\hline Journalism Background & $0.057(0.178)$ & $-0.561(0.304)^{*}$ \\
\hline Age & $5.474(0.516) * * *$ & $4.269(0.906) * * *$ \\
\hline Tenure & $0.475(0.117)^{* * *}$ & $1.998(0.251)^{* * *}$ \\
\hline Vote Percentage & $-1.454(0.704)^{* *}$ & $-0.262(1.102)$ \\
\hline Seat Change & $-2.004(0.547)^{* * *}$ & $1.053(0.822)$ \\
\hline Ineligible for Pension & $-0.383(0.320)$ & $1.099(0.524)^{*}$ \\
\hline Female & $-0.096(0.157)$ & $0.380(0.263)$ \\
\hline Constant & $-24.697(2.004) * * *$ & $-26.501(3.420) * * *$ \\
\hline $\begin{array}{l}\text { Parliamentary Term Dummies } \\
\text { Likelihood Ratio } \chi^{2} \\
\text { McFadden's R }{ }^{2} \\
\text { MPs (Total } \mathrm{n} \text { ) }\end{array}$ & $\begin{array}{l}\text { Yes } \\
633 . \\
0.20 \\
1950\end{array}$ & $\begin{array}{l}* * * \\
5682)\end{array}$ \\
\hline
\end{tabular}

$* \mathrm{p}<0.10, * * \mathrm{p}<0.05, * * * \mathrm{p}<0.01$, two-tailed tests. Coefficients with standard errors clustered by MP in parentheses. 
Table 3: Using MPs' Ideology to Predict Retirement from the British House of Commons, $1997-2010$

\section{Variables}

Left-Right Ideology

Conservative

Liberal/Liberal Democrat

Cabinet Member

Business Background

Law Background

Journalism Background

Age

Tenure

Vote Percentage

Ineligible for Pension

Female

Constant

Parliamentary Term Dummies

Likelihood Ratio $\chi^{2}$

McFadden's $\mathrm{R}^{2}$

MPs (Total $\mathrm{n}$ )

\section{Left Politics}

$0.274(0.122)^{* *}$

$-1.213(0.613)^{* *}$

$-1.198(0.787)$

$0.632(0.634)$

$-0.319(0.427)$

$-0.292(0.612)$

$0.680(0.529)$

$8.988(1.989) * * *$

$0.377(0.387)$

$-2.878(2.497)$

$-0.737(0.832)$

$0.483(0.396)$

$-38.767(7.956)^{* * *}$

Yes

$53.90 * * *$

0.26 452 (590)

$* \mathrm{p}<0.10, * * \mathrm{p}<0.05, * * * \mathrm{p}<0.01$, two-tailed tests. Coefficients with standard errors clustered by MP in parentheses. SNP MPs omitted due to the small number of such MPs. 
Figure 1: The Predicted Probabilities of Retiring Across the Range of Left-Right Ideology

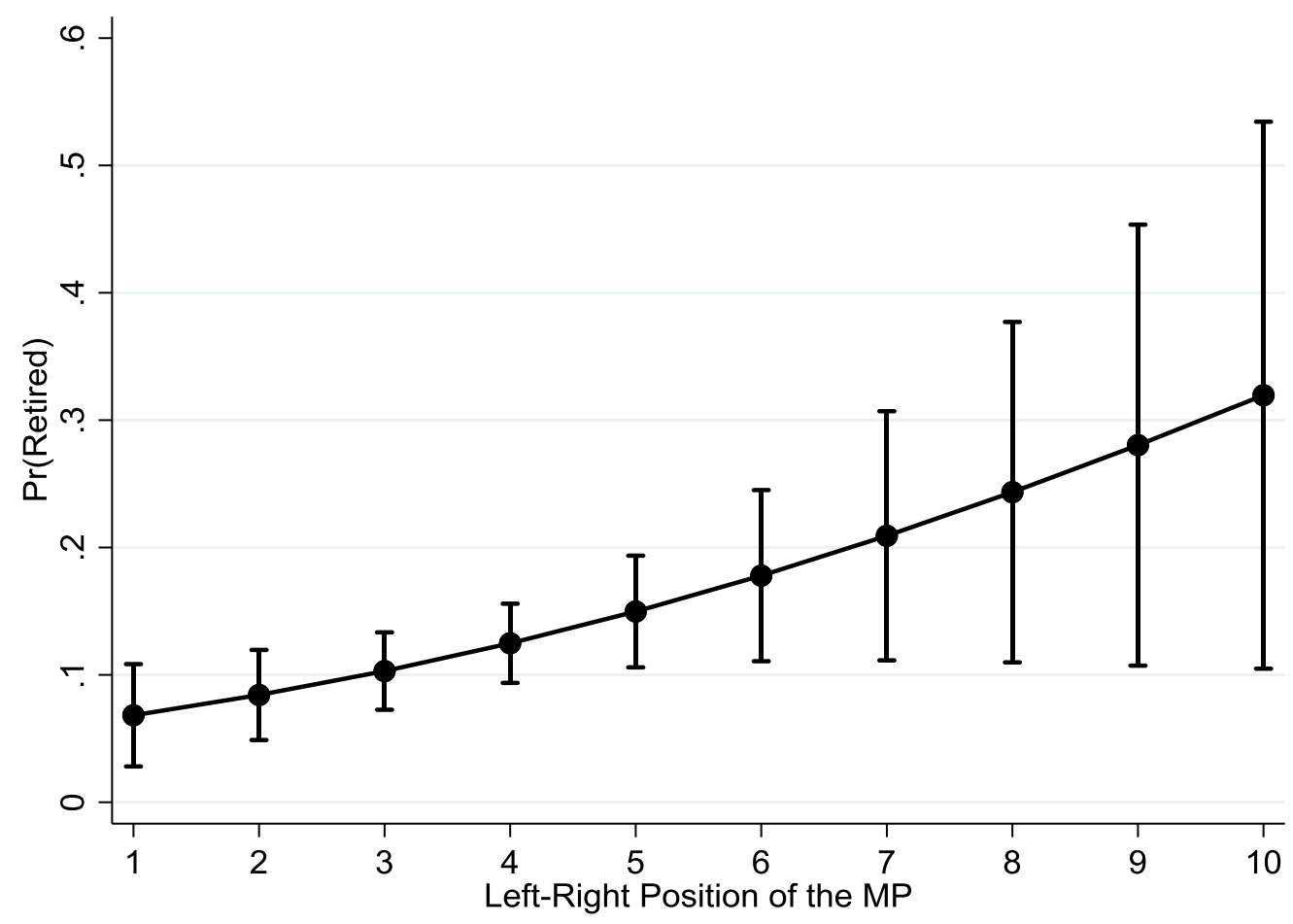

Notes: dots represent the predicted probabilities of retiring while bars represent $95 \%$ confidence intervals. 


\section{Supplemental File for Calling it Quits: Legislative Retirements in Comparative Perspective}

This supplemental file presents parameter estimates from robustness tests of the analyses seen in the main file. Specifically, Tables S.1-S.3 below mirror Tables 1-3 in the main text, but omit those MPs experiencing 'involuntary' exits from Parliament (i.e., it omits MPs during the term in which they lost in their re-election bids). The results confirm the substantive findings reported in the main text, particularly as it relates to the partisan differences in retirement rates.

Table S.4 replaces the variable measuring the changes in parties' seat shares with a variable measuring the anticipated changes in parties' vote shares. Using data from Pack (2019), who collected polling data measuring voting intentions for each election, we created a variable measuring the change in parties' vote shares that would be predicted at the start of the election. Specifically, we take parties' vote shares in the previous election and subtract these from the parties' average intended vote share in the year leading up to the date on which Parliament was dissolved. (Data for the SNP were not available.) The results in Table S.4 confirm the results in Table 2: although the sign of the coefficient for the effect of Conservative MPs on leaving office is reversed, it nonetheless remains statistically insignificant - while the variable measuring changes in parties' anticipated vote shares is statistically significant. Moreover, Liberal/Liberal Democrat MPs remain significantly less likely to leave politics than Labour MPs and significantly more likely to leave Westminster for another office. While we lack comparable data for Canada, the data in Table S.4 suggest that MPs may retire early when they anticipate that their party is likely to suffer major losses in the upcoming election based on pre-election polling.

Tables S.5 and S.6 test the robustness of the findings seen in Tables 1 and 2 further by omitting the variable measuring changes in parties' seat shares. The results show that the findings seen in Tables 1 and 2 are not dependent on the inclusion of the variable measuring changes in parties' seat shares. Reform/Conservative MPs in Canada are significantly more likely to leave politics than Liberal MPs, while there is no significant difference between Conservative and Labour MPs in Britain. Bloc Québécois and SNP MPs remain significantly more likely to retire to pursue other political offices, as are Liberal/Liberal Democrat MPs in Britain.

\section{Reference}

Pack M (2019) Voting intention opinion polls 1943-present: Q1 2019. Accessed at: https://www.markpack.org.uk/158256/voting-intention-opinion-polls-1943-presentq1-2019/. 
Table S.1: Predicting Retirement from the Canadian House of Commons, Excluding Defeated MPs

\begin{tabular}{|c|c|c|}
\hline \multirow[b]{2}{*}{ Variables } & \multicolumn{2}{|c|}{ Outcome } \\
\hline & Left Politics & Other Office \\
\hline Reform/Conservative & $0.471(0.218)^{* *}$ & $-0.866(0.667)$ \\
\hline Progressive Conservative & $0.147(0.576)$ & $1.293(0.977)$ \\
\hline Bloc Québécois & $0.501(0.312)$ & $1.423(0.590)^{* *}$ \\
\hline New Democratic Party & $0.150(0.312)$ & $-0.228(0.696)$ \\
\hline Cabinet Member & $0.032(0.218)$ & $-1.317(0.670)^{* *}$ \\
\hline Governing Party & $-0.060(0.220)$ & $-0.466(0.744)$ \\
\hline Business Background & $-0.075(0.159)$ & $<-0.001(0.370)$ \\
\hline Law Background & $-0.193(0.212)$ & $-0.248(0.466)$ \\
\hline Journalism Background & $0.372(0.294)$ & $0.369(0.575)$ \\
\hline Age & $4.072(0.560)^{* * *}$ & $-0.787(0.787)$ \\
\hline Tenure & $0.664(0.257) * * *$ & $1.064(0.610)^{*}$ \\
\hline Vote Percentage & $-3.020(0.764) * * *$ & $3.928(1.849)^{* *}$ \\
\hline Seat Change & $-0.806(0.871)$ & $-2.689(1.676)$ \\
\hline Pension Eligible & $0.535(0.300)^{*}$ & $1.591(0.889)^{*}$ \\
\hline Pension Maxed & $0.823(0.478)^{*}$ & $2.394(1.240)^{*}$ \\
\hline Female & $-0.018(0.183)$ & $-0.038(0.440)$ \\
\hline Constant & $-16.668(2.256)^{* * *}$ & $-4.185(3.140)$ \\
\hline Parliamentary Term Dummies & \multicolumn{2}{|l|}{ Yes } \\
\hline Likelihood Ratio $\chi^{2}$ & \multicolumn{2}{|c|}{$253.68 * * *$} \\
\hline McFadden's $\mathrm{R}^{2}$ & \multicolumn{2}{|c|}{0.19} \\
\hline MPs (Total n) & \multicolumn{2}{|c|}{$668(1806)$} \\
\hline
\end{tabular}

$* \mathrm{p}<0.10, * * \mathrm{p}<0.05, * * * \mathrm{p}<0.01$, two-tailed tests. Coefficients with standard errors clustered by MP in parentheses. 
Table S.2: Predicting Retirement from the British House of Commons, Excluding Defeated MPs

\begin{tabular}{|c|c|c|}
\hline \multirow[b]{2}{*}{ Variables } & \multicolumn{2}{|c|}{ Outcome } \\
\hline & Left Politics & Other Office \\
\hline Conservative & $0.041(0.127)$ & $0.160(0.203)$ \\
\hline Liberal/Liberal Democrat & $-0.448(0.321)$ & $1.785(0.298)^{* * *}$ \\
\hline Scottish National Party & $-0.077(0.737)$ & $3.253(0.484)^{* * *}$ \\
\hline Cabinet Member & $-0.583(0.259)^{* *}$ & $0.807(0.255)^{* * *}$ \\
\hline Governing Party & $-0.018(0.138)$ & $0.168(0.220)$ \\
\hline Business Background & $-0.212(0.142)$ & $-0.434(0.210)^{* *}$ \\
\hline Law Background & $-0.076(0.147)$ & $0.219(0.210)$ \\
\hline Journalism Background & $0.052(0.184)$ & $-0.580(0.306)^{*}$ \\
\hline Age & $5.616(0.529) * * *$ & $4.268(0.917) * * *$ \\
\hline Tenure & $0.428(0.120)^{* * *}$ & $1.964(0.255)^{* * *}$ \\
\hline Vote Percentage & $-2.841(0.752) * * *$ & $-0.968(1.127)$ \\
\hline Seat Change & $-3.296(0.550) * * *$ & $-0.337(0.839)$ \\
\hline Ineligible for Pension & $-0.511(0.334)$ & $1.058(0.522)^{* *}$ \\
\hline Female & $-0.109(0.161)$ & $0.376(0.263)$ \\
\hline Constant & $-24.280(2.055)^{* * *}$ & $-25.857(3.471)^{* * * *}$ \\
\hline Parliamentary Term Dummies & \multicolumn{2}{|l|}{ Yes } \\
\hline Likelihood Ratio $\chi^{2}$ & \multicolumn{2}{|c|}{$645.03 * * *$} \\
\hline McFadden's $\mathrm{R}^{2}$ & \multicolumn{2}{|c|}{0.22} \\
\hline MPs (Total n) & \multicolumn{2}{|c|}{$1760(5123)$} \\
\hline
\end{tabular}

$* \mathrm{p}<0.10, * * \mathrm{p}<0.05, * * * \mathrm{p}<0.01$, two-tailed tests. Coefficients with standard errors clustered by MP in parentheses. 
Table S.3: Using MPs' Ideology to Predict Retirement from the British House of Commons, 2001-2010

\begin{tabular}{lll}
\hline Variables & All MPs & $\begin{array}{l}\text { Excluding } \\
\text { Defeated MPs }\end{array}$ \\
\hline Left-Right Ideology & $0.274(0.122)^{* *}$ & $0.276(0.131)^{* *}$ \\
Conservative & $-1.213(0.613)^{* *}$ & $-1.417(0.656)^{* *}$ \\
Liberal/Liberal Democrat & $-1.198(0.787)$ & $-1.402(0.804)^{*}$ \\
Cabinet Member & $0.632(0.634)$ & $0.656(0.643)$ \\
Business Background & $-0.319(0.427)$ & $-0.303(0.438)$ \\
Law Background & $-0.292(0.612)$ & $-0.291(0.623)$ \\
Journalism Background & $0.680(0.529)$ & $0.637(0.529)$ \\
Age & $8.988(1.989)^{* * *}$ & $8.892(1.961)^{* * *}$ \\
Tenure & $0.377(0.387)$ & $0.400(0.381)$ \\
Vote Percentage & $-2.878(2.497)$ & $-4.257(2.681)$ \\
Ineligible for Pension & $-0.737(0.832)$ & $-0.830(0.843)$ \\
Female & $0.483(0.396)$ & $0.554(0.386)$ \\
Constant & $-38.767(7.956)^{* * *}$ & $-37.637(6.879)^{* * *}$ \\
Parliamentary Term Dummies & Yes & Yes \\
Likelihood Ratio $\chi^{2}$ & $53.90^{* * *}$ & $52.96 * * *$ \\
McFadden's R & 0.26 & 0.27 \\
MPs (Total n) & $452(590)$ & $432(554)$ \\
\hline
\end{tabular}

$* \mathrm{p}<0.10, * * \mathrm{p}<0.05, * * * \mathrm{p}<0.01$, two-tailed tests. Coefficients with standard errors clustered by MP in parentheses. SNP MPs omitted due to the small number of such MPs. 
Table S.4: Predicting Retirement from the British House of Commons, Replacing the Variable Measuring Seat Share Changes with a Polling-Based Measure

\begin{tabular}{|c|c|c|}
\hline \multirow[b]{2}{*}{ Variables } & \multicolumn{2}{|c|}{ Outcome } \\
\hline & Left Politics & Other Office \\
\hline Conservative & $-0.132(0.122)$ & $0.193(0.216)$ \\
\hline Liberal/Liberal Democrat & $-0.901(0.339)^{* * *}$ & $1.814(0.343)^{* * *}$ \\
\hline Cabinet Member & $-0.540(0.253)^{* *}$ & $0.817(0.252)^{* * *}$ \\
\hline Governing Party & $-0.044(0.150)$ & $0.201(0.242)$ \\
\hline Business Background & $-0.248(0.140)^{*}$ & $-0.454(0.213)^{* *}$ \\
\hline Law Background & $-0.118(0.143)$ & $0.221(0.209)$ \\
\hline Journalism Background & $0.069(0.180)$ & $-0.570(0.315)^{*}$ \\
\hline Age & $5.500(0.521)^{* * *}$ & $4.342(0.929) * * *$ \\
\hline Tenure & $0.478(0.118)^{* * *}$ & $1.957(0.253)^{* * *}$ \\
\hline Vote Percentage & $-1.702(0.702)^{* *}$ & $-0.063(1.124)$ \\
\hline Polling - Previous Vote Share & $-2.004(0.547)^{* * *}$ & $1.053(0.822)$ \\
\hline Ineligible for Pension & $-0.492(0.341)$ & $0.742(0.604)$ \\
\hline Female & $-0.135(0.158)$ & $0.321(0.276)$ \\
\hline Constant & $-24.660(2.025)^{* * *}$ & $-26.710(3.512)^{* * *}$ \\
\hline Parliamentary Term Dummies & \multicolumn{2}{|l|}{ Yes } \\
\hline Likelihood Ratio $\chi^{2}$ & \multicolumn{2}{|c|}{$599.11 * * *$} \\
\hline McFadden's $\mathrm{R}^{2}$ & \multicolumn{2}{|c|}{0.20} \\
\hline MPs (Total n) & \multicolumn{2}{|c|}{$1881(5576)$} \\
\hline
\end{tabular}

$* \mathrm{p}<0.10, * * \mathrm{p}<0.05, * * * \mathrm{p}<0.01$, two-tailed tests. Coefficients with standard errors clustered by MP in parentheses. 
Table S.5: Predicting Retirement from the Canadian House of Commons, Removing the Variable Measuring Seat Share Changes

\begin{tabular}{|c|c|c|}
\hline \multirow[b]{2}{*}{ Variables } & \multicolumn{2}{|c|}{ Outcome } \\
\hline & Left Politics & Other Office \\
\hline Reform/Conservative & $0.524(0.196)^{* * *}$ & $-0.526(0.593)$ \\
\hline Progressive Conservative & $0.197(0.558)$ & $1.200(0.952)$ \\
\hline Bloc Québécois & $0.405(0.296)$ & $1.144(0.549)^{* *}$ \\
\hline New Democratic Party & $0.121(0.306)$ & $-0.245(0.682)$ \\
\hline Cabinet Member & $-0.002(0.214)$ & $-1.349(0.671)^{* *}$ \\
\hline Governing Party & $-0.020(0.190)$ & $-0.691(0.681)$ \\
\hline Business Background & $-0.116(0.153)$ & $-0.007(0.364)$ \\
\hline Law Background & $-0.159(0.196)$ & $-0.263(0.465)$ \\
\hline Journalism Background & $0.269(0.277)$ & $0.338(0.602)$ \\
\hline Age & $3.972(0.563)^{* * *}$ & $-0.998(0.796)$ \\
\hline Tenure & $0.896(0.250)^{* * *}$ & $1.333(0.584)^{* *}$ \\
\hline Vote Percentage & $-1.725(0.724) * *$ & $4.848(1.815)^{* * *}$ \\
\hline Pension Eligible & $0.373(0.285)$ & $1.435(0.864)^{*}$ \\
\hline Pension Maxed & $0.568(0.458)$ & $2.043(1.189)^{*}$ \\
\hline Female & $0.042(0.173)$ & $-0.063(0.446)$ \\
\hline Constant & $-17.085(2.256)^{* * *}$ & $-3.922(3.126)$ \\
\hline Parliamentary Term Dummies & \multicolumn{2}{|l|}{ Yes } \\
\hline Likelihood Ratio $\chi^{2}$ & \multicolumn{2}{|c|}{$247.30 * * *$} \\
\hline McFadden's $\mathrm{R}^{2}$ & \multicolumn{2}{|c|}{0.17} \\
\hline MPs (Total n) & \multicolumn{2}{|c|}{$840(2177)$} \\
\hline
\end{tabular}

$* \mathrm{p}<0.10, * * \mathrm{p}<0.05, * * * \mathrm{p}<0.01$, two-tailed tests. Coefficients with standard errors clustered by MP in parentheses. 
Table S.6: Predicting Retirement from the British House of Commons, Removing the Variable Measuring Seat Share Changes

\begin{tabular}{lll}
\hline \multirow{2}{*}{ Variables } & \multicolumn{2}{c}{ Outcome } \\
\cline { 2 - 3 } Conservative & Left Politics & Other Office \\
Liberal/Liberal Democrat & $-0.091(0.122)$ & $0.168(0.202)$ \\
Scottish National Party & $-0.561(0.309)^{*}$ & $1.669(0.285)^{* * *}$ \\
Cabinet Member & $0.268(0.631)$ & $3.083(0.478)^{* * *}$ \\
Governing Party & $-0.536(0.251)^{* *}$ & $0.824(0.253)^{* * *}$ \\
Business Background & $0.290(0.110)^{* * *}$ & $0.073(0.194)$ \\
Law Background & $-0.239(0.140)^{*}$ & $-0.486(0.209)^{* *}$ \\
Journalism Background & $-0.123(0.143)$ & $0.215(0.208)$ \\
Age & $0.062(0.179)$ & $-0.572(0.303)^{*}$ \\
Tenure & $5.482(0.516)^{* * *}$ & $4.209(0.905)^{* * *}$ \\
Vote Percentage & $0.514(0.115)^{* * *}$ & $2.007(0.254)^{* * *}$ \\
Ineligible for Pension & $-1.848(0.695)^{* * *}$ & $-0.018(1.097)$ \\
Female & $-0.370(0.320)$ & $1.132(0.527)^{* *}$ \\
Constant & $-0.085(0.156)$ & $0.372(0.262)$ \\
Parliamentary Term Dummies & $-24.671(2.001)^{* * *}$ & $-26.296(3.410)^{* * *}$ \\
Likelihood Ratio $\chi^{2}$ & \multicolumn{2}{c}{ Yes } \\
McFadden's R ${ }^{*} \quad 605.47 * * *$ \\
MPs (Total n) & \multicolumn{2}{c}{0.20} \\
\hline$*$ & \multicolumn{2}{c}{$1950(5682)$} \\
\hline
\end{tabular}

$* \mathrm{p}<0.10, * * \mathrm{p}<0.05, * * * \mathrm{p}<0.01$, two-tailed tests. Coefficients with standard errors clustered by MP in parentheses. 